\title{
Numerical simulation with hardening soil model parameters of marine clay obtained from conventional tests
}

\author{
Samaila Saleh ${ }^{1,2}$ (1) $\cdot$ Nor Zurairahetty Mohd Yunus ${ }^{1} \cdot$ Kamarudin Ahmad $^{1} \cdot$ Khairun Nissa Mat Said $^{1}$
}

Received: 22 September 2020 / Accepted: 29 December 2020 / Published online: 19 January 2021

(C) The Author(s) 2021 OPEN

\begin{abstract}
Over the last decades, numerical modelling has gained practical importance in geotechnical engineering as a valuable tool for predicting geotechnical problems. An accurate prediction of ground deformation is achieved if models that account for the pre-failure behaviour of soil are used. In this paper, laboratory results of the consolidated drain (CD) triaxial compression tests and one-dimensional consolidation tests of marine clay were used to determine the hardening soil model (HSM) parameter for use in Plaxis 3D analyses. The parameters investigated for the HSM were stiffness, strength and advanced parameters. The stiffness parameters were secant stiffness in CD triaxial compression test $\left(E_{50}^{\text {ref }}\right)$, tangent stiffness for primary oedometer loading test $\left(E_{\text {oed }}^{\text {ref }}\right)$, unloading/reloading stiffness $\left(E_{\text {ur }}^{\text {ref }}\right)$ and power for the stress-level dependency of stiffness $(m)$. The strength parameters were effective cohesion $\left(c_{\text {ref }}^{\prime}\right)$, effective angle of internal friction $\left(\phi^{\prime}\right)$ and angle of dilatancy $\left(\psi^{\prime}\right)$. The advanced parameters were Poisson's ratio for unloading-reloading $(v)$ and $K_{0}$-value for normal consolidation $\left(K_{\circ}^{\mathrm{nc}}\right)$. Furthermore, Plaxis 3D was used to simulate the laboratory results to verify the effectiveness of this study. The results revealed that the stiffness parameters $E_{50}^{\text {ref }}, E_{\text {oed }}^{\text {ref }}, E_{\text {ur }}^{\text {ref }}$ and $\mathrm{m}$ are equal to $3.4 \mathrm{MPa}, 3.6 \mathrm{MPa}$, $12 \mathrm{MPa}$ and 0.7 , respectively, and that the strength parameters $c_{\text {ref }^{\prime}} \phi^{\prime}, \psi^{\prime}$ and $K_{\circ}^{\text {nc }}$ are equal to $33 \mathrm{kPa}, 17.51^{\circ}, 1.6^{\circ}$ and 0.7 , respectively. A final comparison of the laboratory results with the numerical results revealed that they were in accordance, which proved the efficacy of the study.
\end{abstract}

Keywords Marine clay $\cdot$ Plaxis 3D $\cdot$ Hardening soil model $\cdot$ Model parameters

\section{Introduction}

The application of numerical analysis in geotechnical engineering is becoming a popular and common practise in enhancing engineering projects [1]. Nevertheless, the quality of any calculation rests on the suitability of the model assumed in the study. Generally, an accurate forecast of ground deformation can only be achieved when models that account for the pre-failure behaviour of soil are used [2,3]. Modelling such behaviour with non-linear elasticity is characterised as a robust disparity in stiffness of soil, which is influenced by the degree of strain levels that occurs at stages of construction. Stiffness at pre-failure is crucial in modelling distinctive geotechnical problems such as retaining walls, supporting deep excavations or excavating a tunnel in a developed city.

Although linear constitutive models are commonly used in numerical analyses [4-8], actual soil behaviour is not as simple as it is represented in simple linear constitutive models. Soil behaviour is complicated in nature because soil is a multi-phase material that exhibits not only elastic, plastic and non-linear deformations but also irreversible plastic strains [9]. Depending on the stress history, soil may be compressed or dilated. Elasto-plastic models with linear elasticity such as the Mohr-Coulomb model (MCM) cannot reproduce a change in stiffness, as

$\checkmark$ Samaila Saleh, samailasaleh@graduate.utm.my| ${ }^{1}$ School of Civil Engineering, Universiti Teknologi Malaysia, Johor Bahru, Malaysia. ${ }^{2}$ Department of Civil Engineering, Hassan Usman Katsina Polytechnic, Katsina 820241, Nigeria. 
shown between points A, B and D in Fig. 1. Soil stiffness depends on the degree of stress-levels and deformations of soil are time-dependent. Indeed, soil behaviour is considered to be elastic in the small strain range; soil stiffness is nearly recoverable in unloading conditions. However, in the analysis of pre-failure non-linearities of soil behaviour, one may observe a substantial variation of stiffness starting from very small to very large shear strain.

Engineers who are looking for reliable forecasts of engineering system response and who apply linear-elastic, perfectly plastic models in the finite element analysis may underrate ground deformation. Numerical analyses in the MCM do not differentiate loading and unloading stiffness moduli, hence leading to an unrealistic lifting of the retaining wall linked with the unloading of the bottom of the excavation [10]. Similarly, Mohr-Coulomb assumed linearelastic soil behaviour before failure; however, in reality, overconsolidated clays exhibit a reduction of stiffness at stress-levels below the typical expected values that cause failure [11]. Furthermore, the MCM assumes that stiffness parameters are not dependent on the stress-level. Therefore, it cannot symbolise a change in plastic strains, whilst unloading the soil.

The hardening soil model (HSM) is an advanced elastoplastic constitutive model that is used for simulating both stiff and soft soil behaviours [12]. HSM also relates stiffness parameters to the stress-level and simulates the development of plastic strains under compressive loading. HSM is an extension of the hyperbolic model established by Duncan and Chang [13]. It supersedes the Duncan and Chang [13] model by using plasticity theory instead of elasticity

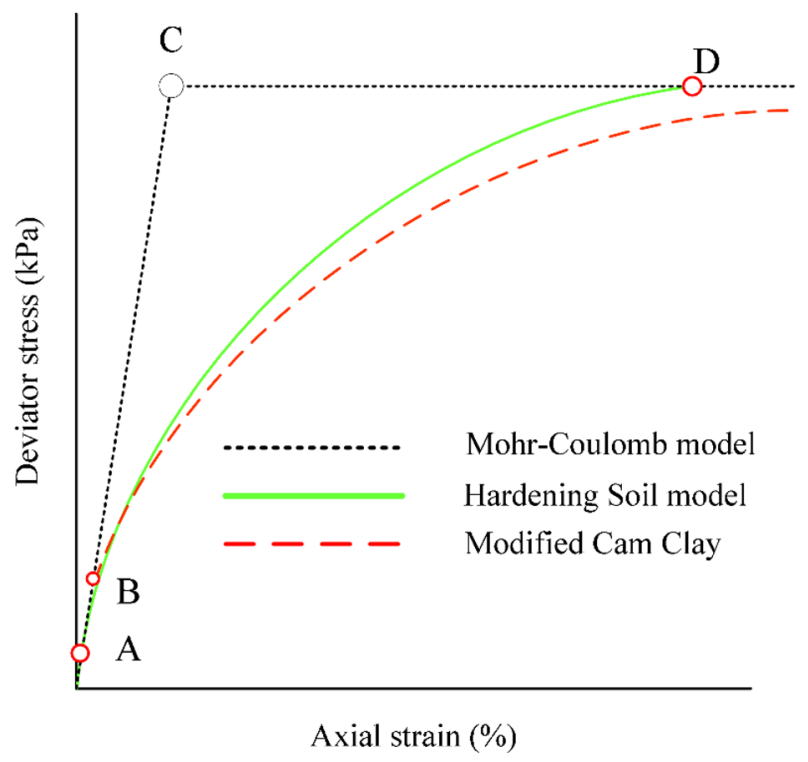

Fig. 1 Comparison of stress-strain curves of different models for drained triaxial compression theory. It also includes the dilatancy of soil and introduces a yield cap. The yield surface of the HSM can expand as a result of plastic straining, unlike the elastic perfectly plastic model in which the yield surface is fixed in a principal stress space. At very low strain levels $\left(<10^{-5}\right)$ most soils exhibit higher stiffness than at engineering strain levels, and this stiffness varies non linearly with strain. In that case, the hardening soil model with small-strain (HSsmall model) is ideal for the analyses of both static and dynamic tasks [14]. HSsmall model is a modification of the HS model, which is concerned with improving soil stiffness in small strains.

HSM has two types of hardening: shear and compressive hardening. The difference between the two is that shear hardening is used for modelling permanent strains caused by principal deviator loading, whereas compression hardening is used for modelling permanent plastic strains caused by primary oedometric compression and isotropic load [15]. Despite the mathematical intricacy of the HSM, its parameters can be obtained from conventional soil tests due to their clear physical meaning. Therefore, in this paper, HSM parameters of marine clay (MC) were determined by using CD triaxial compression and oedometer test results. Furthermore, a simulation of the laboratory result was conducted in the Plaxis 3D software. The laboratory test results were validated with the numerical results to verify the effectiveness of this study.

Information from the literature revealed that some few studies have been performed on determination of model parameters. For example, Wu and Tung [16] developed a protocol for determining HSM parameters of gravelly soils using result of triaxial compression test. Their findings revealed the model parameters determined showed very good simulation of the measured data from triaxial tests and fields experiments with applied loads of up to $1000 \mathrm{kPa}$. Similarly, triaxial behaviour of riverbed and blasted quarried rockfill materials was modelled by Honkanadavar and Sharma [17] with HSM using triaxial compression results. Their results showed that the analysis of the elastic and shear strength parameters of the simulated and experimentally determined parameters found that both findings were closely matched. Finite element analysis and a parameter optimization algorithm were combined by Calvello and Finno [18] to effectively calibrate a soil model by minimising errors between experimental and numerical result. The obtained results indicated that the computed results match the experimental data. Stiffness parameters of residual soil at a deep excavation construction site in the Kenny Hill Formation were determined [19]. The result of parametric studies using HSM demonstrated that the horizontal deflection of the wall at each point of excavation was reasonably predictable with clear correlations between stiffness parameters and $\mathrm{N}$ value of standard penetration test. Application of the HS model has shown 
that the model is not only suitable for the study of the case of the Kenny Hill Formation, but can also be applied from a practical point of view to similar soils with these types of problems. The above and many more studies, such as those of $[18,20,21]$ have led to research interest in determine HSM parameter of $M C$ using results of $C D$ triaxial compression test, oedometer test and particles size distribution test.

\section{Material and method}

The material used for this research is a disturbed sample of MC collected from Batu Pahat, Malaysia. The collected MC sample was air-dried, pulverised and stored in plastic containers. Index tests were conducted on the MC sample to identify and classify the soil. The results of the index tests were as previously reported [22], and MC was classified as clay of high plasticity $(\mathrm{CH})$.

\subsection{Consolidated drain (CD) triaxial compression test}

The shear strength of the $M C$ was measured using $C D$ triaxial compression test following BS:1377-8 [23]. The cylindrical specimens (size of $38 \mathrm{~mm}$ diameter and $76 \mathrm{~mm}$ ) were also prepared from remoulded MC mixed at the optimum moisture content [24]. To enhance the rate of saturation and consolidation, a vertical drain was fixed around the sample (see Fig. 2a) using filter paper, then placed in the triaxial cell, as shown in Fig. 2b. Important devices of the triaxial machine, such as the load cell, linear vertical displacement transducer (LVDT), volume change and pressure transducers, were calibrated prior to the beginning of the test. The equipment was connected to a computer's high-precision efficient real-time data acquisition function for automated recording and processing of data.

Using the method of back-pressure saturation, the saturation was achieved. Throughout the saturation stage, a $10 \mathrm{kPa}$ backpressure difference was maintained until a Skempton B-check of at least 0.95 was obtained [25]. Subsequently, after completion of the saturation of the specimen, the next stage was consolidation with varying effective stresses of $100 \mathrm{kPa}, 200 \mathrm{kPa}$ and $300 \mathrm{kPa}$ [26]. Shearing was carried out at the end of the consolidation stage by estimating the shearing rate from $t_{100}$ of the consolidation curve using Eq. (1). During the shearing, the drainage line was opened (back pressure valve). The triaxial test equipment used in this research is shown in Fig. 2c.

$t_{\mathrm{f}}=14 \times t_{100}$

$t_{f}$, time to failure for CD test with side drain; $t_{100}$ is the intercept of tangent lines touching initial portion and horizontal portion of volume change vs square root time curve of consolidation stage.

\subsection{One-dimensional consolidation test}

Test of MC consolidation characteristics was carried out as per of BS:1377-5 [27] using unsaturated MC. The specimen was prepared for soil compacted in cylindrical moulds with a diameter of $50 \mathrm{~mm}$ and a height of $20 \mathrm{~mm}$. The test was carried out using a load sequence ranging from 10 to $1000 \mathrm{kPa}$ with twice the load increment ratio. The pressure was maintained constant for $24 \mathrm{~h}$ during each loading cycle. The unloading was carried out in a similar way at the end of the last loading cycle. The compression gauge readings and the corresponding time intervals were automatically recorded at every stage of the test using a data logger connected to the computer.

\subsection{Particle size distribution}

Due to the higher precision, reliability of results and speed of the operation, the particle size distribution of the MC was carried out using the Laser diffraction method following the standard ISO:13320 (2009) procedure [28, 29]. Approximately, $50 \mathrm{~g}$ of the air-dried MC sample was soaked for $24 \mathrm{~h}$ in a dispersion agent to come up with a solution. One litre of distiled water, $7 \mathrm{~g}$ of sodium carbonate and $33 \mathrm{~g}$ of sodium hexametaphosphate were used to produce the dispersion agent. The soaked MC was mixed for 30 min using a mechanical mixer to obtain a homogeneous solution for particle size distribution test using a Laser diffraction machine model LA960V2 HORIBA.

\subsection{Numerical simulation of the laboratory results}

The numerical simulation of the MC laboratory result was performed in a separate window in the Plaxis software. As shown in Fig. 3a, an input parameter was entered and the test was run. The deviator stress vs axial strain curve was selected (Fig. 3b), and the data were imported to excel where the curves of both numerical and experimental results were plotted.

\section{Results and discussions}

The following sub-section provides the discussion of both the experimental and numerical results.

\subsection{Strength parameters}

The strength parameters were obtained using the results of the CD triaxial compression test. The parameters 
Fig. 2 Triaxial apparatus set up for the $C D$ triaxial tests: a shows triaxial cell, $\mathbf{b}$ shows vertical drain in the triaxial sample and c complete triaxial machine

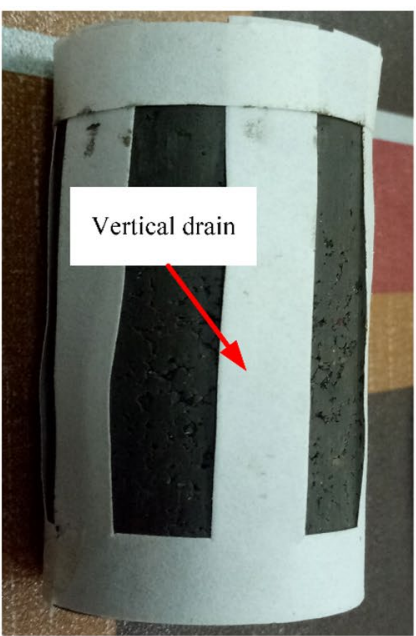

(a)

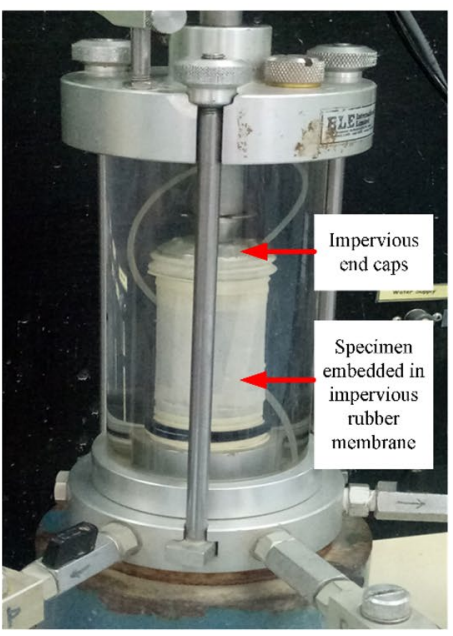

(b)

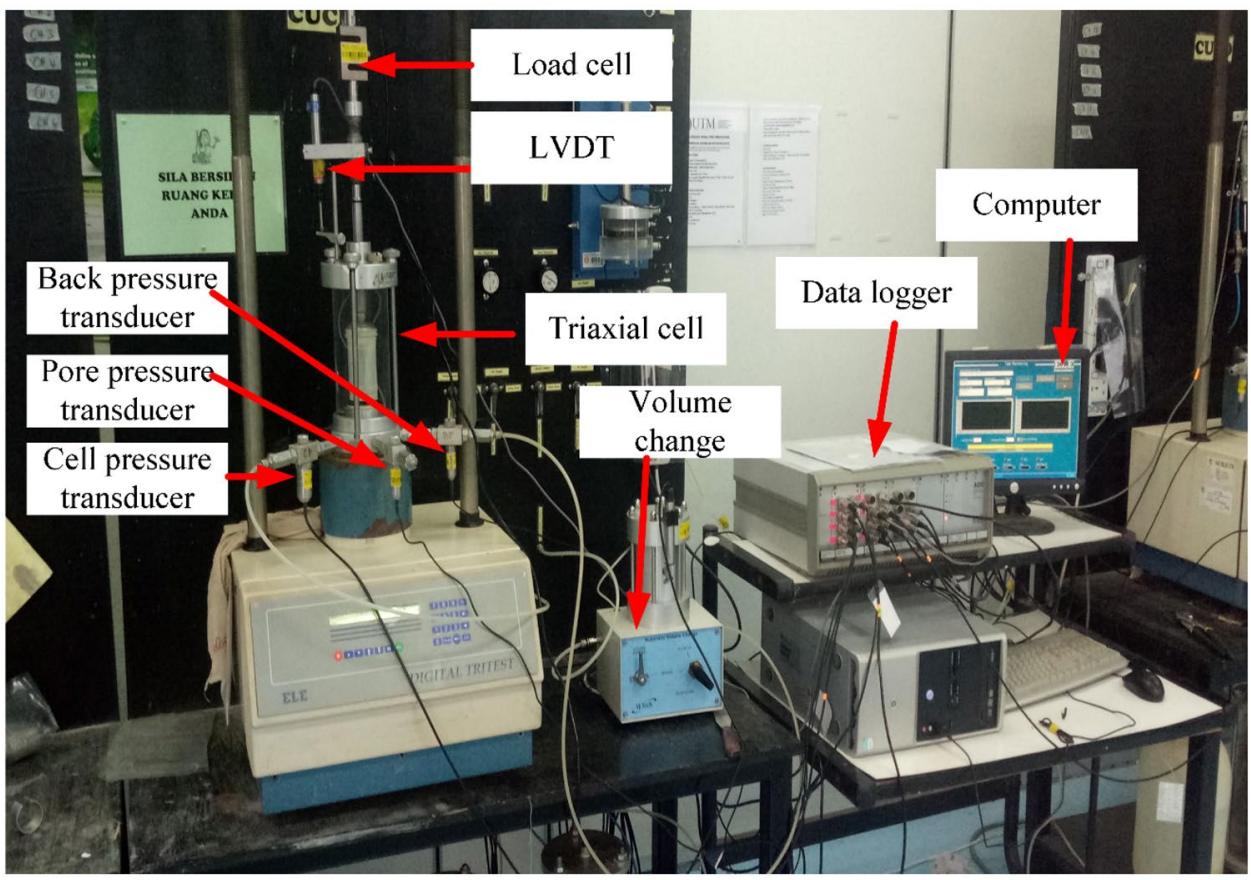

(c) obtained were $c_{\text {ref }}^{\prime}\left(\mathrm{kN} / \mathrm{m}^{2}\right), \phi^{\prime}$ (degree), and $\psi^{\prime}$ (degree). Three confining pressures were adopted in $C D$ triaxial compression tests: $100 \mathrm{kPa}, 200 \mathrm{kPa}$ and $300 \mathrm{kPa}$, respectively. The summary of the effective major and minor principal stresses at the failure of the three specimens are presented in Table 1. Figure 4 shows the Mohr circles of effective stresses, which specifies the conditions at the failure of the $C D$ triaxial compression test. From the results, the strength parameters, $c_{\text {ref }}^{\prime}$ and $\phi^{\prime}$ were found to be $33.58 \mathrm{kPa}$ and $17.51^{\circ}$, respectively.

The dilatancy angle, $\psi^{\prime}$ was obtained from the gradient of the axial strain-volumetric strain curve, as shown in
Fig. 5. Based on the curve, only $100 \mathrm{kPa}$ confining pressure showed some or little dilatancy. When the confining pressure exceeds $100 \mathrm{kPa}$, the dilatancy disappears [30, 31]. From Fig. 5, for the $100 \mathrm{kPa}$ confining pressure curve, using 0.0564 as the value for $\mathrm{d}$, the dilatancy angle computed using Eq. (2) was 1.6 degrees.

$\psi=-\sin ^{-1}\left(\frac{d}{2-d}\right)$ 


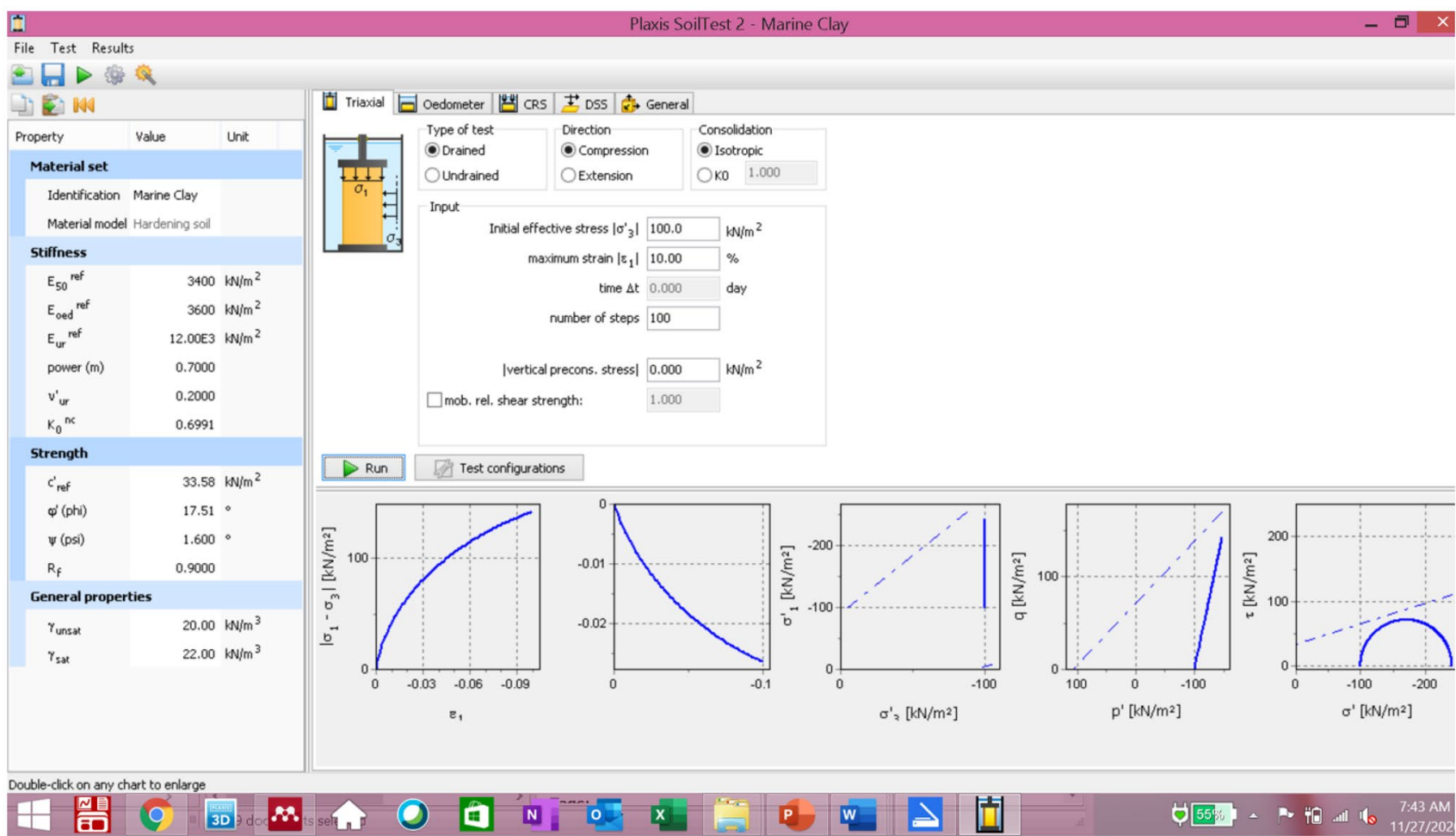

(a)

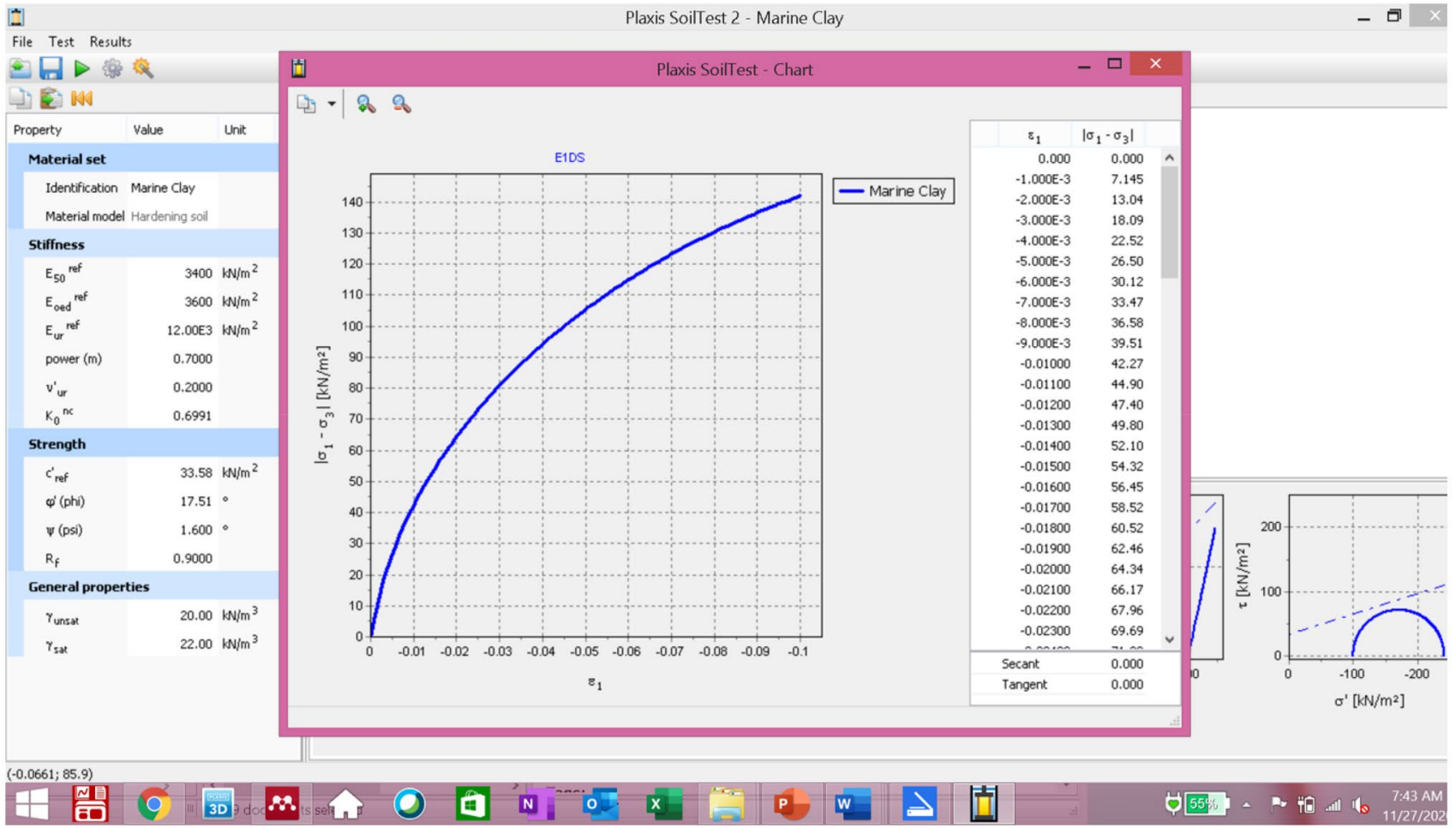

(b)

Fig. 3 Simulation of marine clay properties in Plaxis 3D $\mathbf{a}$ inputting the model parameters and $\mathbf{b}$ collecting the simulated results 
Table 1 Summary of specimen details at failure during CD triaxial compression test

\begin{tabular}{lll}
\hline $\begin{array}{l}\text { Specimen refer- } \\
\text { ence }\end{array}$ & $\begin{array}{l}\text { Effective minor principal } \\
\text { stress }\left(\sigma_{3}^{\prime}\right)(\mathrm{kPa})\end{array}$ & $\begin{array}{l}\text { Effective major } \\
\text { principal stress }\left(\sigma_{1}^{\prime}\right) \\
(\mathrm{kPa})\end{array}$ \\
\hline A & 83.2 & 247.3 \\
B & 195.7 & 452.9 \\
C & 307.1 & 661.5 \\
\hline
\end{tabular}

\subsection{Stiffness parameter}

The stiffness parameters were obtained using the results of the $C D$ triaxial compression test and oedometer test. The parameters obtained were $E_{50}^{\text {ref }}\left(\mathrm{kN} / \mathrm{m}^{2}\right)$ in the $C D$ triaxial compression test, $E_{\text {ged }}^{\text {ref }}\left(\mathrm{kN} / \mathrm{m}^{2}\right)$ for primary oedometer loading test, $E_{\mathrm{ur}}^{\mathrm{ref}}\left(\mathrm{kN} / \mathrm{m}^{2}\right)$, and power for the stress-level dependency of stiffness, $m$.

The values for $E_{50}^{\text {ref }}$ and $m$ that were obtained by plotting the deviator stresses against the axial strains for each confining pressures are shown in Fig. 6 . In addition, the moduli $E_{50}$, corresponding to each of them, were determined as $3159 \mathrm{kPa}, 4296 \mathrm{kPa}$ and $5428 \mathrm{kPa}$, respectively.

The value for stiffness stress dependency parameter $\mathrm{m}$ was obtained using the trend line based on Eq. 3. The values for the $y$ variables were assigned as $\ln E_{50}$ and $x$ variables as $\ln \left(\frac{\sigma_{3}^{\prime}+c^{\prime} \cot \phi^{\prime}}{100+c^{\prime} \cot \phi^{\prime}}\right)$ [32], as shown in Fig. 7. The slope of the trend line was the value for the stiffness stress dependency parameter $m$ and was found to be equal to 0.7 . $y=a x+b$

The secant stiffness of the $C D$ triaxial compression test $\left(E_{50}^{\text {ref }}\right)$ was computed using Eq. (4) for each of the three respective effective stress, $\sigma_{3}^{\prime}$, using the corresponding moduli $E_{50}$, as shown in Table 2 . The values for effective $c^{\prime}, \phi^{\prime}$ and $\mathrm{m}$ were already obtained as $33.51 \mathrm{kPa}, 17.580$ and 0.7 ,

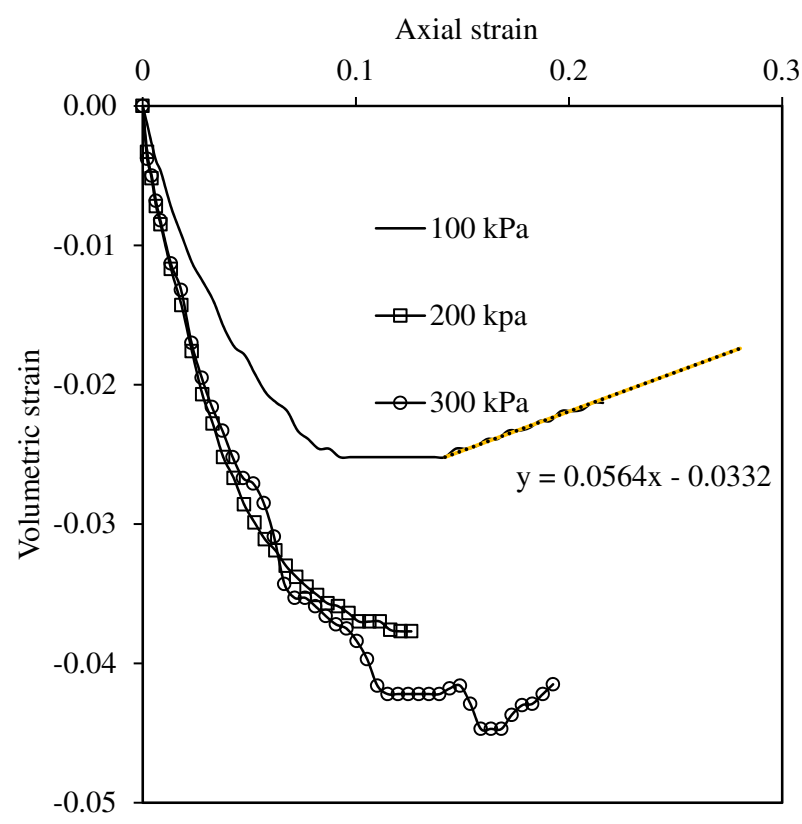

Fig. 5 Determination of dilatancy angle
Fig. 4 Mohr circle of CD triaxial compression test result

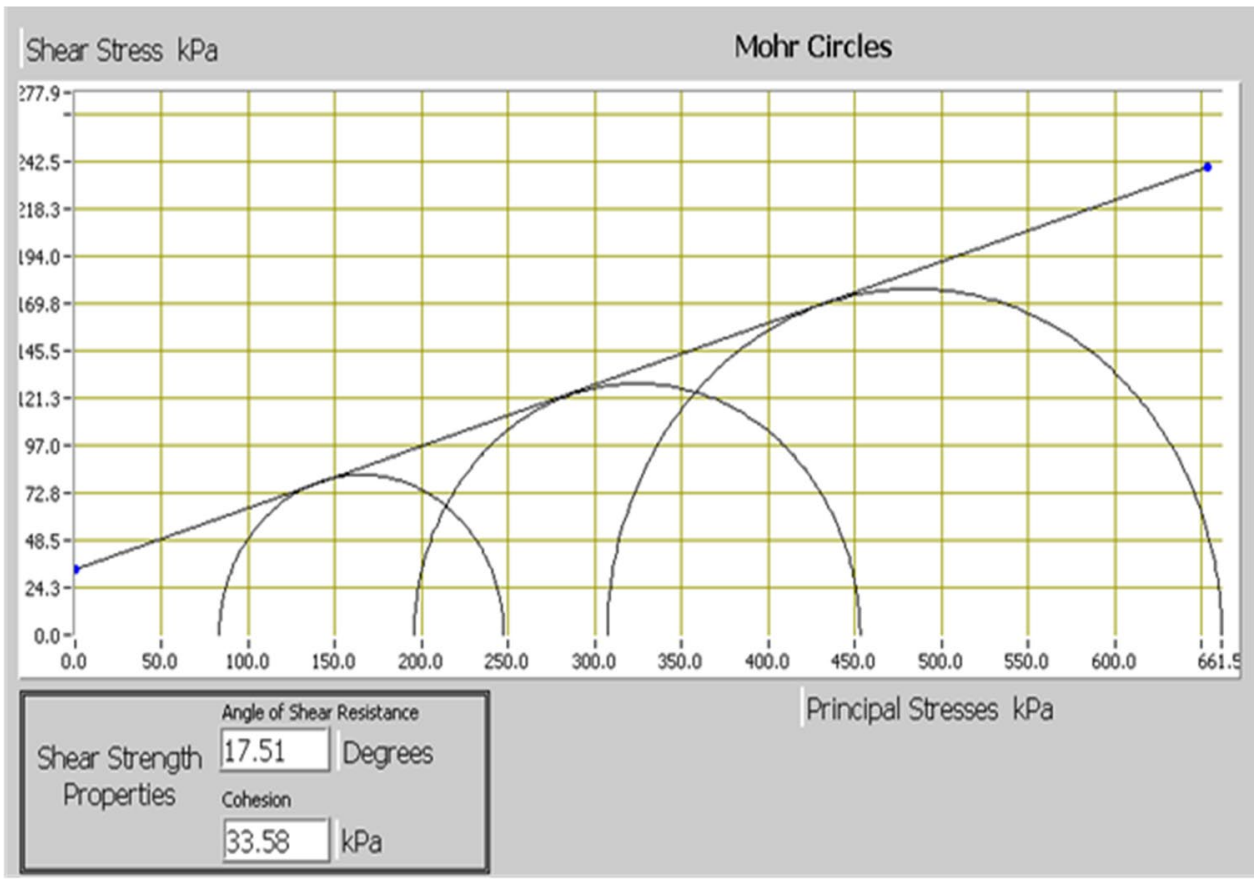




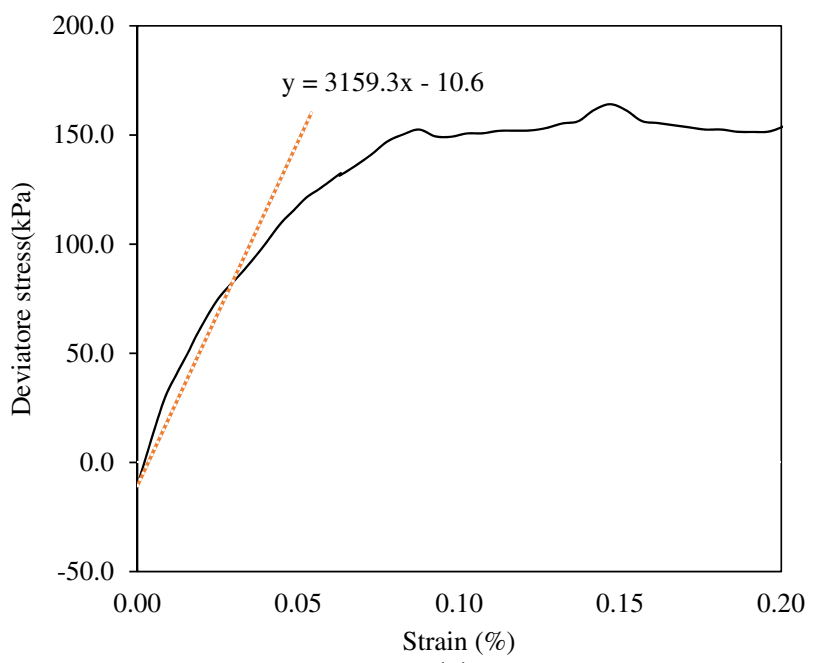

(a)

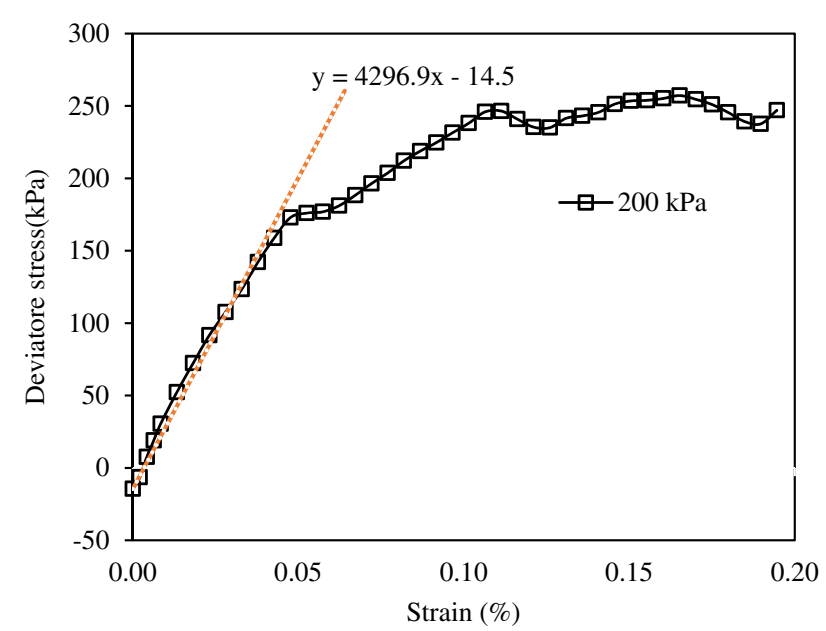

(b)

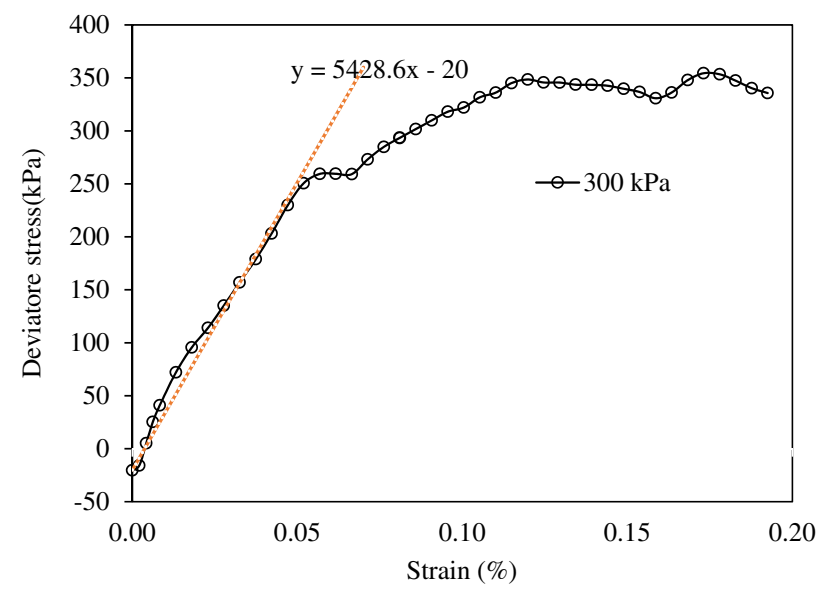

(c)

Fig. 6 Determination of $E_{50}$ moduli from the curves of deviator stress vs axial strain of drained triaxial compression tests at $\mathbf{a}$ $100 \mathrm{kPa}, \mathbf{b} 200 \mathrm{kPa}$ and c $300 \mathrm{kPa}$ cell pressure



Fig. 7 Determination of stiffness stress dependency $(m)$ parameter

respectively. Therefore, the average value of $E_{50}^{\text {ref }}$ was found to be approximately 3.4 MPa.

$E_{50}=E_{50}^{\mathrm{ref}}\left(\frac{\sigma_{3}^{\prime}+c^{\prime} \cot \phi^{\prime}}{100+c^{\prime} \cot \phi^{\prime}}\right)^{m}$

$E_{50}^{\text {ref }}$, secant stiffness in CD triaxial compression test $(\mathrm{kN} /$ $\left.\mathrm{m}^{2}\right) ; E_{50}$, moduli $E_{50}$ corresponding to effective stress, $\sigma_{3}^{\prime}$ $\left(\mathrm{kN} / \mathrm{m}^{2}\right) ; \sigma_{3}^{\prime}$, effective minor principal stress $\left(\mathrm{kN} / \mathrm{m}^{2}\right) ; m$, power for stress-level dependency of stiffness (parameter $\mathrm{m}) ; c^{\prime}\left(\mathrm{kN} / \mathrm{m}^{2}\right)$, effective cohesion; $\phi^{\prime}$, effective angle of internal friction (degree); $\psi^{\prime}$, angle of dilatancy (degree).

The result of the consolidation test of $M C$ is presented in Fig. 8. From the result, the compression index $c_{c}$ was found to be equal to 0.1943 . The tangent modulus $E_{\text {oed }}$ and Oedometer tangent stiffness and $E_{\text {oed }}^{\text {ref }}$ post-yielding of the primary loading was computed using Eqs. 5 and 6. The value of the $E_{\text {oed }}^{\text {ref }}$ was computed to be equal to $3.6 \mathrm{MPa}$.

$E_{\text {oed }}=\frac{2.3\left(1+e^{\text {ref }}\right) \sigma_{\text {oed }}^{\text {ref }}}{c_{c}}$

$E_{\mathrm{oed}}=E_{\mathrm{oed}}^{\mathrm{ref}}\left(\frac{\sigma_{3}^{\prime}+c^{\prime} \cot \phi^{\prime}}{100+c^{\prime} \cot \phi^{\prime}}\right)^{m}$

Table 2 Determination of secant stiffness of the CD triaxial test, $E_{50}^{\text {ref }}$

\begin{tabular}{llll}
\hline$\sigma_{3}^{\prime}(\mathrm{kPa})$ & $E_{50}(\mathrm{kPa})$ & $\left(\frac{\sigma_{3}^{\prime}+c^{\prime} \cot \phi^{\prime}}{100+c^{\prime} \cot \phi^{\prime}}\right)^{m}$ & $E_{50}^{\text {ref }}(\mathrm{kPa})$ \\
\hline 83.2 & 3159 & 0.94 & 3471.429 \\
195.7 & 4296 & 1.31 & 3279.389 \\
307.1 & 5428 & 1.62 & 3350.617 \\
Average & & & 3367.145 \\
\hline
\end{tabular}




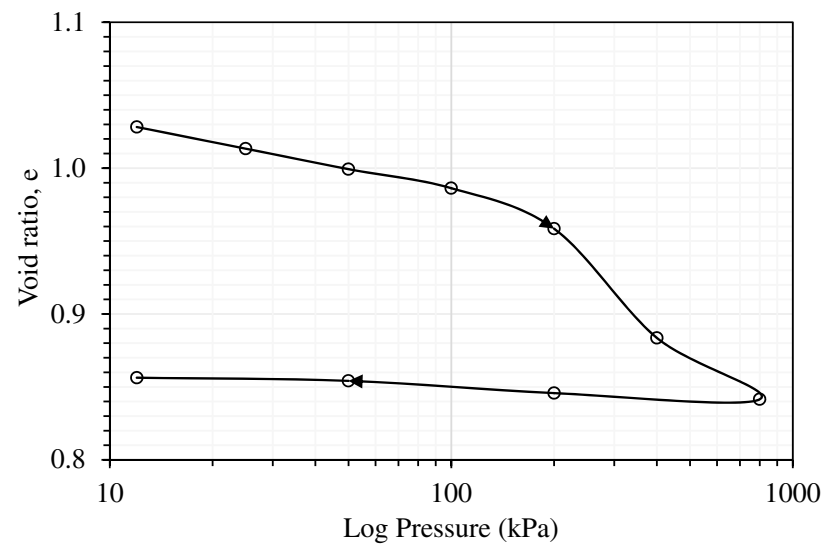

Fig. 8 Determination of Oedometer tangent modulus $E_{\text {oed }}$ from the result of consolidation test

$E_{\text {oed }}$, oedometer tangent modulus; $E_{\text {oed }}^{\text {ref }}$ oedometer tangent stiffness; $\sigma_{\text {oed }}^{\text {ref }}$ stress at which the marine clay undergoes plastic straining; $e^{\text {ref }}$, Void ratio corresponding to stress $\sigma_{\text {ref }}^{\text {red }}$ at which the material undergoes plastic straining; $c_{C}$, compression index.

Note that $\sigma_{\text {oed }}^{\text {ref }}$ and $e^{\text {ref }}$ are relevant to the material that undergoes plastic straining, that is, the stress point that lies on the primary loading curve. The unloading-reloading modulus $E_{\text {ur }}^{\text {ref }}$ was estimated to have a value varying between 3 and 5 times the $E_{50}^{\text {ref }}$ Plaxis-3D [33] and Wang et al. [34].

\subsection{Stiffness advanced parameters}

The advanced stiffness parameters were estimated based on the recommendation of Plaxis-3D [33]. The parameters for the advanced stiffness were Poisson's ratio for unloading-reloading (default $v=0.2$ ), reference stress for stiffnesses (default $p^{\text {ref }}=100 \mathrm{kN} / \mathrm{m}^{2}$ ) and $K_{0}$-value for normal consolidation (default $K_{\circ}^{\mathrm{nc}}=1-\sin \phi$ ). The recommended values for the stiffness advanced parameters are the default values [33].

\subsection{Particle sizes distribution}

The result of the particle size distribution of $M C$ is shown in Fig. 9. From the result, particles smaller than $2 \mu \mathrm{m}$, particles between $2 \mu \mathrm{m}$ and $50 \mu \mathrm{m}$ and particles bigger than $50 \mu \mathrm{m}$ were $3 \%, 75 \%$ and $22 \%$, respectively. The result for the particle size distribution was also applied in the Plaxis software, whilst performing the simulation.

\subsection{Comparison of experimental and numerical results}

Table 3 shows a summary of the HSM parameters obtained for all the studies. The listed parameters were inputted into the HSM in Plaxis 3D software, and stress-strain curves from the $C D$ triaxial compression tests were obtained. Figure 10 shows the comparison of the numerical and experimental results of the CD triaxial compression test of the $\mathrm{MC}$ at three different confining pressures. The comparison demonstrates that the HSM can simulate the stress and strain behaviour of the MC. The above comparison is also in agreement with the comparison report by Wang et al. [34].

\subsection{Discussion of experimental results}

Discussion of the properties of MC was carried out by comparing the properties of $\mathrm{MC}$ in this research with other $\mathrm{MC}$ properties from different parts of the world published
Fig. 9 Result for the particles sizes distribution

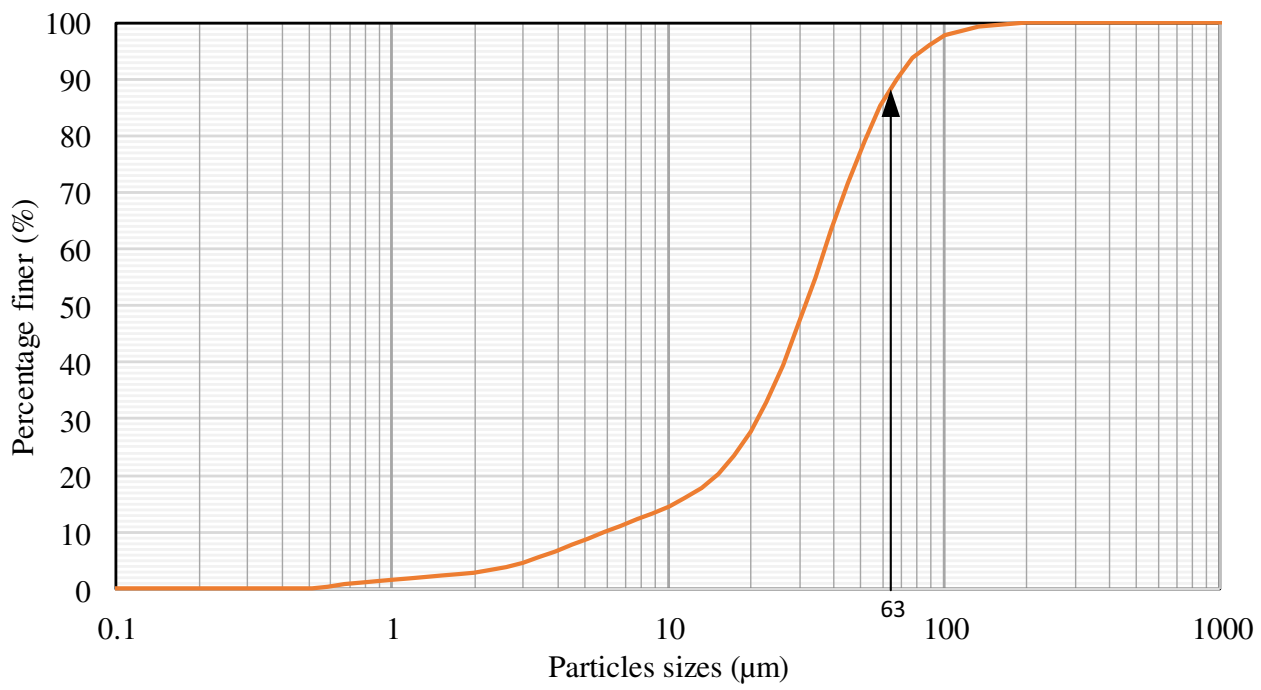


Table 3 Summary of experimental results

\begin{tabular}{lll}
\hline Parameters & Unit & Values \\
\hline Secant stiffness in CD triaxial compression test $\left(E_{50}^{\text {ref }}\right)$ & $\mathrm{kN} / \mathrm{m}^{2}$ & 3400 \\
Tangent stiffness for primary oedometer loading test $\left(E_{\text {oed }}^{\text {ref }}\right)$ & $\mathrm{kN} / \mathrm{m}^{2}$ & 3600 \\
Unloading/reloading stiffness $\left.\left(E_{\mathrm{ur}}^{\text {ref }}\right)\right)$ & $\mathrm{kN} / \mathrm{m}^{2}$ & 12,000 \\
Stress-level of stiffness, $\mathrm{m}$ & - & 0.7 \\
Effective cohion, $c^{\prime}(\mathrm{kPa})$ & $\mathrm{kN} / \mathrm{m}^{2}$ & 33.58 \\
Effective friction angle, $\phi^{\prime}$ & $\mathrm{degree}$ & 17.51 \\
Dilatancy angle, $\psi^{\prime}$ & $\mathrm{degree}$ & 1.6 \\
Poisson's ratio, $\nu$ & - & 0.2 \\
Reference stress for stiffnesses $p^{\text {ref }}$ & $\mathrm{kN} / \mathrm{m}^{2}$ & 100 \\
$\mathrm{~K}_{0}$-value for normal consolidation, $K^{\mathrm{nc}}$ & - & 0.7 \\
Compression index, $C_{\mathrm{c}}$ & - & 0.1943 \\
Initial void ratio & - & 1.0282 \\
Saturated unit weight $\gamma_{\text {sat }}$ & $\mathrm{kN} / \mathrm{m}^{3}$ & 22 \\
Particles sizes $\leq 2 \mu \mathrm{m}$ & $\%$ & 3 \\
Particles sizes $2-50 \mu \mathrm{m}$ & $\%$ & 75 \\
Particles sizes $\geq 50 \mu \mathrm{m}$ & $\%$ & 22 \\
\hline
\end{tabular}

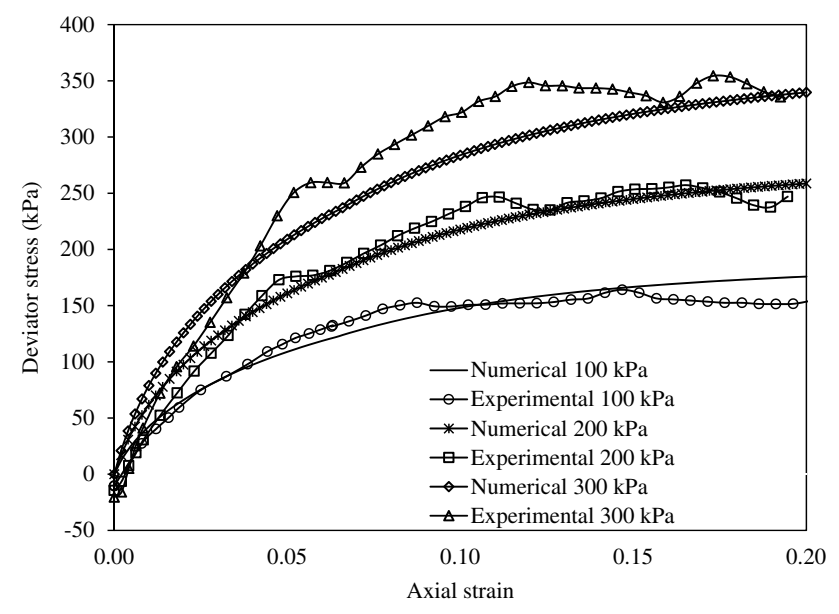

Fig. 10 Comparison of laboratory test with the numerical analysis

in the literature. The discussion covered in this paper is limited to the result of shear strength and consolidation properties of the MC as well as result of particles size distribution and numerical simulation of the HSM of the MC. Index properties, geochemistry, microstructure and toxicity of the MC are not cover in this paper because they were reported earlier in previous research [22, 35-37].

The shear strength of soil depends on the water content, mineral content and the degree of consolidation of the soil $[38,39]$. Triaxial tests are commonly used to test the shear strength of the MC. In this research, the shear strength parameters of the $M C$ were determined using consolidated drained (CD) triaxial tests. The result obtained showed that the effective cohesion, $c^{\prime}$ and effective angle of internal friction, $\phi^{\prime}$ were found to be $33.58 \mathrm{kPa}$ and $17.51^{\circ}$, respectively.

The $c^{\prime}$ values for the MC in this study is marginally higher than those reported for MC from central Iran and Kedda Malaysia $[40,41]$ whose both reported $c^{\prime}$ of $25 \mathrm{kPa}$. Likewise, another MC from south China sea [42], and Thaniland [43] had $c^{\prime}$ of 20 and $18 \mathrm{kPa}$, respectively. Similarly, Pakir [44] and Sunny and Joy [45] also recorded much lower value of $c^{\prime}, 10 \mathrm{kPa}$ and $9 \mathrm{kPa}$ for MC collected from Johor Malaysia and Kerala India. On the other hand, the values of $\phi^{\prime}$ for the MC in this research is lower than that MC from Thailand and Johor Malaysia in which $\phi^{\prime}$ was equal to $25^{\circ}$ and $22^{\circ}$, respectively $[43,44]$. The value of the $\phi^{\prime}$ was higher than that reported by Ouhadi et al. [40] who reported $\phi^{\prime}$ of $15^{\circ}$.

Compression index $\left(c_{\mathrm{c}}\right)$, swelling index $\left(c_{\mathrm{s}}\right)$ and initial void ratio $\left(e_{0}\right)$ are amongst the parameters that can be obtained from the consolidation test. The results of this research showed that the value for the $c_{c}$ of $M C$ are 0.194 . Comparison of the consolidation properties of the MC in this research and other $M C$ from published literatures showed that the $c_{c}$ of the $M C$ is about similar to the $M C$ from Ningbo city, China [46] and Johor Malaysia [44] in which the $c_{c}$ values were 0.18 and 0.22 , respectively. The value of the $c_{c}$ is lower than the other MC from Singapore $[47,48]$ in which the value ranges between 0.6 and 1.5 . Other MC from Kedah Malaysia and Pathumthani Thailand were also reported to have relatively higher $c_{c}$ value between 0.57 and $1.67[41,49]$.

The value $c_{s}$ of the $M C$ was 0.014 , is slightly lower than that of MC from Perak Malaysia, Ningbo city China and Johor Malaysia in which their $c_{\mathrm{s}}$ values were $0.02,0.035$, and 0.04 , respectively $[44,46,50]$. Singapore $M C$ had $c_{s}$ 


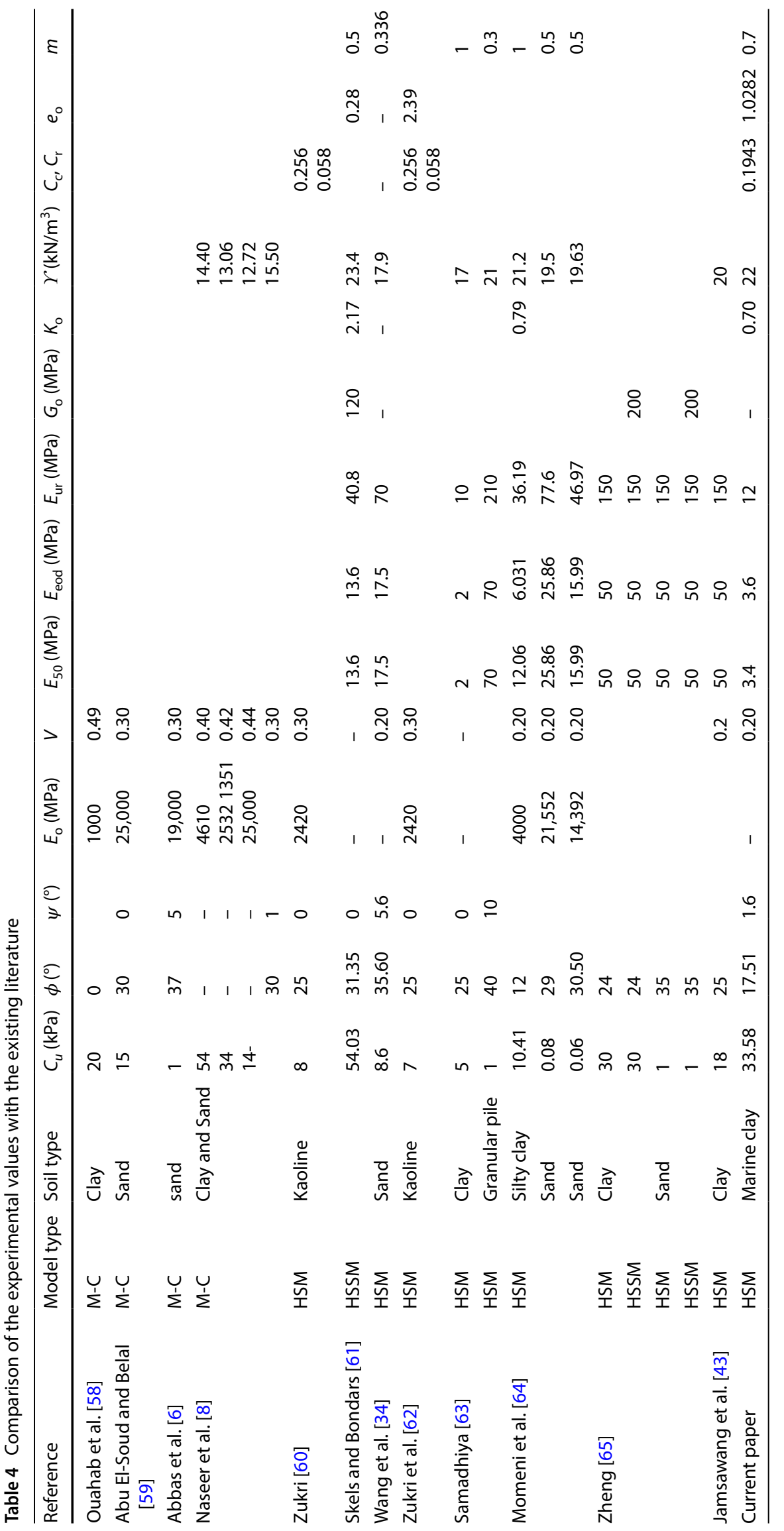


between 0.06 and $0.16[47,48]$; similarly, Thailand MC has $c_{\mathrm{s}}$ values of 0.14 [49]. The value of $e_{o}$ of the MC under review was 1.03 , and it was slightly higher than the $M C$ from Johor which has $e_{o}$ equal to 0.85 . The $e_{0}$ value is slightly lower than the $\mathrm{MC}$ from Ningbo City China and Port Harcourt Nigeria which have $e_{0}$ value 1.22 and 0.83 to 1.5 , respectively $[46,51]$. Other MC from Thailand, Perak Malaysia, Changi Singapore and South China Sea had higher $e_{o}$ values that ranges between 1.8 and 3.3 [42, 47, $49,50]$. The variation in the consolidation properties of the various $M C$ is linked to the water content, permeability, structural arrangement and porosity of the soil particles [52].

The results for the particle size distribution revealed that the proportion of fine particles below $63 \mu \mathrm{m}$ (clay and silt) in the MC is about $88 \%$. Ouhadi et al. [40] and Otoko and Simon [51] reported that MC from cental Iran and Port Harcourt Nigeria had $78 \%$ and $91 \%$ fine particles. Similarly, other MC from China and Thailand had proportion of fine particles between $94 \%$ and $96 \%[49,53,54]$. Pakbaz and Alipour [55] and Sunny and Joy [45] both reported 97\% as the proportion of fine particles in the MC from port of Imam Khomeini in southwest of Iran and Thopumpady, Ernakulam, Kerala India. The high composition of fine particles and the presence of swelling mineral like monmorillonite and illite in the $\mathrm{MC}$ are some of the reason that make MC problematic soil for construction purpose $[56,57]$.

\subsection{Comparison of the model parameter with existing research}

Table 4 presents a comparison of the HSM parameters with some other models' parameters reported in current studies. Generally, the majority of the models' parameters reported showed that the researchers used MCM. The model of shear strength parameters shows that cohesion ranges between $1 \mathrm{kPa}$ and $54 \mathrm{kPa}$. Granular soil, sand and very soft clay are reported to have a lower value of cohesion.

The friction angle ranges between 0 and 40 degrees. Clay tested under undrained conditions has zero friction angle, whilst sand and granular soils have a higher friction angle. The result also shows that clay soils have zero dilatancies, whilst sand has a dilatancy angle that ranges between 1 and 10 degrees. By comparing the result of this paper and that of previous studies, it can be said that the values of the shear strength parameters fall within the range of the results reported by many researchers. Similarly, considering the result of stiffness parameters, the values for $E_{50}$ and $E_{\text {oed }}$ range between 2 and $50 \mathrm{MPa}$. Values for $E_{\mathrm{ur}}$ range between 10 and $150 \mathrm{MPa}$. Similarly, values for parameter $\mathrm{m}$ range below 0.5 for sand and between 0.5 and 1 for clay soil. The said stiffness parameter for the current paper also falls within the range reported in prior research.

\section{Conclusion}

From the results obtained by CD triaxial compression test and one-dimensional consolidation tests, the shear strength and stiffness parameters of HSM of MC were determined. The findings could provide a useful reference for conducting numerical analyses on similar soil. The key results are as follows:

1. The values of shear strength parameters obtained are $c_{\text {ref' }}^{\prime} \phi^{\prime}$ and $\psi^{\prime}$, which are equal to $33.58 \mathrm{kPa}, 17.51^{\circ}$ and $1.6^{\circ}$, respectively. The stiffness parameters obtained are $E_{50}^{\text {ref }}, E_{\text {oed }}^{\text {ref }}, E_{\text {ur }}^{\text {ref }}$ and $\mathrm{m}$, which are equal to $3.4 \mathrm{MPa}$, 3.6 $\mathrm{MPa}, 12 \mathrm{MPa}$ and 0.7 , respectively.

2. A simulation of the laboratory result was conducted in the Plaxis 3D software. Comparison of curves for deviator stress versus the axial strain of the laboratory test results were and numerical results showed good fit and that verify the effectiveness of this study.

Acknowledgements The authors are grateful for the support provided by the research grants of UTMFR Vote No. Q.J130000.2551.21 H42 and UTMER Vote No. Q.J130000.2651.18J00 from Universiti Teknologi Malaysia, Johor Bahru, Malaysia. The first author is equally grateful for the support provided by the Tertiary Education Trust Fund (TET Fund) Nigeria.

\section{Compliance with ethical standards}

Conflict of interest On behalf of all authors, the corresponding author states that there is no conflict of interest.

Open Access This article is licensed under a Creative Commons Attribution 4.0 International License, which permits use, sharing, adaptation, distribution and reproduction in any medium or format, as long as you give appropriate credit to the original author(s) and the source, provide a link to the Creative Commons licence, and indicate if changes were made. The images or other third party material in this article are included in the article's Creative Commons licence, unless indicated otherwise in a credit line to the material. If material is not included in the article's Creative Commons licence and your intended use is not permitted by statutory regulation or exceeds the permitted use, you will need to obtain permission directly from the copyright holder. To view a copy of this licence, visit http://creativecommons .org/licenses/by/4.0/. 


\section{References}

1. Ikeagwuani CC, Nwonu DC (2019) Engineering emerging trends in expansive soil stabilisation: a review. J Rock Mech Geotech Eng 11(2):423-440. https://doi.org/10.1016/j.jrmge .2018.08.013

2. Phoon K, Tang C, Phoon K (2019) Characterisation of geotechnical model uncertainty. Georisk Assess Manag Risk Eng Syst Geohazards 13(2):101-130. https://doi.org/10.1080/17499 518.2019 .1585545

3. Sabatakakis N, Tsiambaos G, Ktena S, Bouboukas S (2018) The effect of microstructure on mi strength parameter variation of common rock types. Bull Eng Geol Environ 77(4):1673-1688. https://doi.org/10.1007/s10064-017-1059-7

4. El Kahi E, Deck O, Khouri M, Mehdizadeh R, Rahme P (2020) A new simplified meta-model to evaluate the transmission of ground movements to structures integrating the elastoplastic soil behavior. Structures 23:324-334. https://doi. org/10.1016/j.istruc.2019.10.023

5. Acharyya R (2019) Finite element investigation and ANNbased prediction of the bearing capacity of strip footings resting on sloping ground. Int J Geo Eng. https://doi.org/10.1186/ s40703-019-0100-z

6. Abbas BJ, Aziz HY, Maula BH, Alkateeb RT (2019) Finite element analysis of spread footing near slops. In: IOP conference series materials science and engineering, vol 518, no 2 . https://doi. org/10.1088/1757-899x/518/2/022055

7. Munirwan RP, Munirwansyah M (2019) Escape hill as geotechnical quick response method in facing upcoming tsunami disaster. In: IOP conference series earth environmental science, vol 273, no 1. https://doi.org/10.1088/1755-1315/273/1/012053

8. Naseer S, Sarfraz Faiz M, lqbal S, Jamil SM (2019) Laboratory and numerical based analysis of floating sand columns in clayey soil. Int J Geo Eng 10(1):1-16. https://doi.org/10.1186/s4070 3-019-0106-6

9. Meng F, Chen R, Kang X, Li Z (2020) e-p curve-based structural parameter for assessing clayey soil structure disturbance. Bull Eng Geol Environ. https://doi.org/10.1007/s10064-020-01833-8

10. Capraru C, Adam D, Hoffmann J, Pelzl M (2014) Numerical analysis of deep excavations and prediction of their influence on neighboring buildings. Numer Methods Geotech Eng 1:1. https ://doi.org/10.1201/b17017-132

11. Likitlersuang S, Surarak C, Balasubramania A, Oh E, Ryull KS, Wanatowski D (2013) Duncan-Chang-parameters for hyperbolic stress strain behaviour of soft Bangkok clay. In: 18th international conference on soil mechanics and geotechnical engineering, Paris, pp 381-384. https://doi.org/10.13140 /2.1.3744.8966

12. Schanz T, Vermeer PA, Bonnier PG (1999) The hardening soil model: formulation and verification. In: Beyond 2000 in computational geotechnics. Ten years of PLAXIS International. Proceedings of the international symposium, pp 281-296

13. Duncan JM, Chang CY (1970) Nonlinear analysis of stress and strain in soils. J Soil Mech Found Div 96(SM5):1629-1653

14. Herold A, von Wolffersdorff P-A (2009) The use of hardening soil model with small-strain stiffness for serviceability limit state analyses of GRE structures. GeoAfrica 2009:1-8

15. Brinkgreve R (ed) (1999) Beyond 2000 in computational geotechnics. Routledge, London

16. Wu JTH, Tung SC-Y (2020) Determination of model parameters for the hardening soil model. Transp Infrastruct Geotechnol 7(1):55-68. https://doi.org/10.1007/s40515-019-00085-8

17. Honkanadavar NP, Sharma KG (2016) Modeling the triaxial behavior of riverbed and blasted quarried rockfill materials using hardening soil model. J Rock Mech Geotech Eng 8(3):350 365. https://doi.org/10.1016/j.jrmge.2015.09.007

18. Calvello M, Finno RJ (2004) Selecting parameters to optimize in model calibration by inverse analysis. Comput Geotech 31(5):410-424. https://doi.org/10.1016/j.compgeo.2004.03.004

19. Law KH, Othman $S Z$, Hashim $R$, Ismail $Z$ (2014) Determination of soil stiffness parameters at a deep excavation construction site in Kenny Hill Formation. Measurement 47(1):645-650. https:// doi.org/10.1016/j.measurement.2013.09.030

20. Surarak $C$, Likitlersuang $S$, Wanatowski D, Balasubramaniam A, Oh E, Guan H (2012) Stiffness and strength parameters for hardening soil model of soft and stiff Bangkok clays. Soils Found 52(4):682-697. https://doi.org/10.1016/j.sandf.2012.07.009

21. Fu Y, He S, Zhang S, Yang Y (2020) Parameter analysis on hardening soil model of soft soil for foundation pits based on shear rates in Shenzhen Bay, China. Adv Mater Sci Eng 2020:1-11. https://doi.org/10.1155/2020/7810918

22. Saleh S, Mohd Yunus NZ, Ahmad K, Ali N (2018) Stabilization of marine clay soil using polyurethane. In: MATEC Web conference, vol 250, p 01004. https://doi.org/10.1051/matecconf/20182 5001004

23. BS:1377-8 (1990) Shear strength tests (effective stress). Br. Stand. Inst., London, pp 1-21

24. Paul A, Hussain M (2020) An experiential investigation on the compressibility behavior of cement-treated Indian peat. Bull Eng Geol Environ 79(3):1471-1485. https://doi.org/10.1007/ s10064-019-01623-x

25. Head KH (1998) Manual of soil laboratory testing, vol 3, 2nd edn. Wiley, Hoboken, p 215

26. Elkady TY, Abbas MF, Shamrani MA (2016) Behavior of compacted expansive soil under multi-directional stress and deformation boundary conditions. Bull Eng Geol Environ 75(4):17411759. https://doi.org/10.1007/s10064-015-0839-1

27. BS:1377-5 (1990) Compressibility, permeability and durability tests. Br. Stand. Inst., London, pp 1-19

28. Hemalatha MS, Santhanam M (2018) Characterizing supplementary cementing materials in blended mortars. Constr Build Mater 191:440-459. https://doi.org/10.1016/j.conbuildma t.2018.09.208

29. Hu W, Nie Q, Huang B, Shu X, He Q (2018) Mechanical and microstructural characterization of geopolymers derived from red mud and fly ashes. J Clean Prod 186:799-806. https://doi. org/10.1016/j.jclepro.2018.03.086

30. Cheng Q, Yao K, Liu Y (2018) Stress-dependent behavior of marine clay admixed with fly-ash-blended cement. Int J Pavement Res Technol 11(6):611-616. https://doi.org/10.1016/j.ijprt .2018.01.004

31. Idinger G, Wu W (2019) Recent advances in geotechnical research. Springer International Publishing, Cham

32. Obrzud RF, Truty A (2018) The hardening soil model—a practical guidebook

33. PLAXIS-3D (2017) Plaxis 3D reference manual

34. Wang F, Han J, Corey R, Parsons RL, Sun X (2017) Numerical modeling of installation of steel-reinforced high-density polyethylene pipes in soil. J Geotech Geoenviron Eng 143(11):04017084. https://doi.org/10.1061/(ASCE)GT.1943-5606.0001784

35. Saleh S, Mohd Yunus NZ, Ahmad K, Ali N, Marto A (2020) Microlevel analysis of marine clay stabilised with polyurethane. KSCE J Civ Eng 24(3):807-815. https://doi.org/10.1007/s1220 5-020-1797-0

36. Saleh S, Ahmad K, Mohd Yunus NZ, Hezmi MA (2020) Evaluating the toxicity of polyurethane during marine clay stabilisation. Environ Sci Pollut Res 27(17):21252-21259. https://doi. org/10.1007/s11356-020-08549-y

37. Saleh $S$ et al (2019) Geochemistry characterisation of marine clay. In: IOP conference series materials science and 
engineering, vol 527, p 012023. https://doi.org/10.1088/1757$899 \times / 527 / 1 / 012023$

38. Dehghanbanadaki A (2014) Bearing capacity of peat treated with deep mixing cement columns. Universiti Teknologi Malaysia, Johor

39. Ismail Ibrahim KMH (2015) Effect of percentage of low plastic fines on the unsaturated shear strength of compacted gravel soil. Ain Shams Eng J 6(2):413-419. https://doi.org/10.1016/j. asej.2014.10.012

40. Ouhadi VR, Yong RN, Amiri M, Ouhadi MH (2014) Pozzolanic consolidation of stabilized soft clays. Appl Clay Sci 95:111-118. https://doi.org/10.1016/j.clay.2014.03.020

41. Rahman ZA, Yaacob WZW, Rahim SA, Lihan T, Idris WMR, Mohd Sani WNF (2013) Geotechnical characterisation of marine clay as potential liner material. Sains Malays 42(8):1081-1089

42. Nian T, Jiao H, Fan N, Guo X (2020) Microstructure analysis on the dynamic behavior of marine clay in the South China Sea. Mar Georesour Geotechnol 38(3):349-362. https://doi. org/10.1080/1064119X.2019.1573864

43. Jamsawang P, Phongphinittana E, Voottipruex P, Bergado DT, Jongpradist $P$ (2019) Comparative performances of two- and three-dimensional analyses of soil-cement mixing columns under an embankment load. Mar Georesour Geotechnol 37(7):852-869. https://doi.org/10.1080/1064119X.2018.15042 61

44. Pakir FB (2017) Physicochemical, microstructural and engineering behaviour of non-traditional stabiliser treated marine clay. Universiti Teknologi Malaysia, Johor

45. Sunny T, Joy A (2016) Study on the effects of marine clay stabilized with banana fibre. Int J Sci Eng Res 4(3):96-98

46. Xiong Y, Liu G, Zheng R, Bao X (2018) Study on dynamic undrained mechanical behavior of saturated soft clay considering temperature effect. Soil Dyn Earthq Eng 115(2017):673-684. https://doi.org/10.1016/j.soildyn.2018.09.026

47. Bo MW, Arulrajah A, Sukmak P, Horpibulsuk S (2015) Mineralogy and geotechnical properties of Singapore marine clay at Changi. Soils Found 55(3):600-613. https://doi.org/10.1016/j. sandf.2015.04.011

48. Bo MW, Choa V, Chu J, Arulrajah A, Horpibulsuk S (2017) Laboratory investigation on the compressibility of Singapore marine clays. Mar Georesour Geotechnol 35(6):847-856. https://doi. org/10.1080/1064119X.2016.1256922

49. Phanvisavakarn $P(2018)$ Strain rate and thermal effect on stressstrain behavior of organic clay. Int J Geomater 15(47):193-200. https://doi.org/10.21660/2018.47.GTE164

50. Ali F, Al-Samaraee EAS (2013) Field behavior and numerical simulation of coastal bund on soft marine clay loaded to failure. Electron J Geotech Eng 18S:4027-4042

51. Otoko GR, Simon Al (2015) Stabilization of a deltaic marine clay (Chikoko) with Chloride compounds. Int Res J Eng Technol 02(03):2095-2097

52. Mesri G, Ajlouni M (2007) Engineering properties of fibrous peats. J Geotech Geoenviron Eng 133(7):850-866. https://doi. org/10.1061/(ASCE)1090-0241(2007)133:7(850)
53. Wang J, Guo L, Cai Y, Xu C, Gu C (2013) Strain and pore pressure development on soft marine clay in triaxial tests with a large number of cycles. Ocean Eng 74:125-132. https://doi. org/10.1016/j.oceaneng.2013.10.005

54. Gu C, Wang J, Cai Y, Sun L, Wang P, Dong Q (2016) Deformation characteristics of overconsolidated clay sheared under constant and variable confining pressure. Soils Found 56(3):427-439. https://doi.org/10.1016/j.sandf.2016.04.009

55. Pakbaz MS, Alipour R (2012) Influence of cement addition on the geotechnical properties of an Iranian clay. Appl Clay Sci 67-68:1-4. https://doi.org/10.1016/j.clay.2012.07.006

56. Saleh $S$ et al (2019) Improving the strength of weak soil using polyurethane grouts: a review. Constr Build Mater 202:738-752. https://doi.org/10.1016/j.conbuildmat.2019.01.048

57. Mohammed Al-Bared MA, Marto A (2017) A review on the geotechnical and engineering characteristics of marine clay and the modern methods of improvements. Malays J Fundam Appl Sci 13(4):825-831. https://doi.org/10.11113/mjfas.v13n4.921

58. Ouahab MY, Mabrouki A, Frank R, Mellas M, Benmeddour D (2020) Undrained bearing capacity of strip footings under inclined load on non-homogeneous clay underlain by a rough rigid base. Geotech Geol Eng 38(2):1733-1745. https://doi. org/10.1007/s10706-019-01127-1

59. Abu El-Soud S, Belal AM (2019) Numerical modeling of rigid strip shallow foundations overlaying geosythetics-reinforced loose fine sand deposits. Arab J Geosci 12(7):254. https://doi. org/10.1007/s12517-019-4436-7

60. Zukri A (2019) Soft clay stabilisation using lightweight aggregate for raft and column matrices. Universiti Teknologi Malaysia

61. Skels P, Bondars K (2017) Applicability of small strain stiffness parameters for pile settlement calculation. Procedia Eng 172:999-1006. https://doi.org/10.1016/j.proeng.2017.02.149

62. Zukri A, Nazir R, Shien NK (2018) Settlement prediction of a group of lightweight aggregate (LECA) columns using finite element modelling. Int J Eng Technol 7(4.35):59. https://doi. org/10.14419/ijet.v7i4.35.22324

63. Samadhiya NK (2017) Numerical analysis of anchored granular pile (AGP) under tensile loads. In: 19th international conference on soil mechanics and geotechnical engineering, Seoul, pp 3231-3234

64. Momeni E, Maizir H, Gofar N, Nazir R (2013) Comparative study on prediction of axial bearing capacity of driven piles in granular materials. J Teknol (Sciences Eng) 61(3):15-20. https://doi. org/10.11113/jt.v61.1777

65. Zheng A (2018) Finite element analysis on bearing capacity of post-grouting bored pile with the HS-small model and the HS model. IOP Conf Ser Earth Environ Sci 189(2). https://doi. org/10.1088/1755-1315/189/2/022087

Publisher's Note Springer Nature remains neutral with regard to jurisdictional claims in published maps and institutional affiliations. 